\title{
Upaya Meningkatkan Hasil Belajar Matematika Materi Keliling dan Luas Lingkaran Pada Peserta Didik Melalui Metode Diskusi di Kelas IV SDN 156/X Tanjung Solok Semester Ganjil Tahun Ajaran 2021/2022
}

\author{
Nuraini \\ SDN 156/X Tanjung Solok \\ Jl. Parit Ban RT.19 RW.05 Tanjung Solok \\ Nuraini_@gmail.com
}

\begin{abstract}
This study aims to describe and obtain information on improving mathematics learning outcomes through the discussion method. This research is classroom action research consisting of two cycles, each cycle consisting of two meetings. Each meeting consists of four stages, namely planning, implementation, observation, and reflection. The subjects of this study were the fourths' grade students of SDN 156/X Tanjung Solok, totaling 5 people. This research was conducted in the odd semester of the 2021/2022 academic year. Data collection techniques using tests, observations, and documentation. Data were analyzed using percentages. The results showed that the discussion method could improve the mathematics learning outcomes of fourth grade students at SDN 156/X Tanjung Solok by giving rewards.
\end{abstract}

Keywords: math learning outcomes, discussion

\begin{abstract}
Abstrak
Penelitian ini bertujuan untuk mendeskripsikan dan mendapatkan informasi peningkatan hasil belajar Matematika melalui metode diskusi. Penelitian ini merupakan penelitian tindakan kelas yang terdiri dari dua siklus masing-masing siklus terdiri dari dua kali pertemuan. Masing-masing petemuan terdiri dari empat tahapan yaitu perencanaan, pelaksanaan, observasi dan refleksi. Subjek penelitian ini adalah peserta didik kelas IV SDN 156/X Tanjung Solok yang berjumlah sebanyak 5 orang. Penelitian ini dilaksanakan pada semester ganjil tahun ajaran 2021/2022. Teknik pengumpulan data menggunakan tes, observasi, dan dokumentasi. Data dianalisis menggunakan persentase. Hasil penelitian menunjukkan bahwa melalui metode diskusi dapat meningkatkan hasil belajar Matematika peserta didik kelas IV SDN 156/X Tanjung Solok dengan tindakan pemberian reward.
\end{abstract}

Kata kunci: hasil belajar matematika, diskusi

Copyright (c) 2021 Nuraini

Corresponding author: Nuraini

Email Address: Nuraini_@gmail.com (Jl. Parit Ban RT.19 RW.05 Tanjung Solok)

Received 10 January 2022, Accepted 20 January 2022, Published 31 January 2022

\section{PENDAHULUAN}

Pada dasarnya pendidikan selalu mengalami perubahan, perkembangan dan perbaikan sesuai dengan perkembangan di segala bidang kehidupan. Perubahan dan perbaikan dalam bidang pendidikan meliputi berbagai komponen yang terlibat di dalamnya baik itu pelaksana pendidikan di lapangan (kompetensi guru dan kualitas tenaga pendidik), mutu pendidikan, perangkat kurikulum, sarana dan prasarana pendidikan dan mutu menejemen pendidikan termasuk perubahan dalam metode dan strategi pembelajaran yang lebih inovatif. Upaya perubahan dan perbaikan tersebut bertujuan membawa kualitas pendidikan Indonesia lebih baik.

Istilah mathematics (Inggris), mathematic (Jerman) atau mathematick/wiskunde (Belanda) berasal dari perkataan lain mathematica, yang mulanya diambil dari perkataan Yunani, mathematike, yang berarti relating to learning. Perkataan itu mempunyai akar kata mathema yang berarti 
Upaya Meningkatkan Hasil Belajar Matematika Materi Keliling dan Luas Lingkaran Pada Peserta Didik Melalui Metode Diskusi di Kelas IV SDN 156/X Tanjung Solok Semester Ganjil Tahun Ajaran 2021/2022, Nuraini

pengetahuan atau ilmu (knowledge, science). Perkataan mathematike berhubungan sangat erat dengan sebuah kata lainnya yang serupa, yaitu mathematein yang mengandung arti belajar berpikir (Erman Suherman, 2003:18).

Matematika terdiri dari empat wawasan yang luas, yaitu: Aritmetika, Aljabar, Geometri dan Analisis. Selain itu matematika adalah ratunya ilmu, maksudnya bahwa matematika itu tidak bergantung pada bidang studi lain. Sementara menurut Depdiknas (2006: 346) bahwa matematika meliputi aspek-aspek bilangan, aljabar, geometri dan pengukuran serta statistika dan peluang. Senada dengan pendapat tersebut, James dan James dalam kamus matematikanya (Erman Suherman, 2003:16) mengatakan bahwa matematika adalah ilmu tentang logika mengenai bentuk, susunan, besaran, dan konsepkonsep yang berhubungan satu dengan yang lainnya dengan jumlah yang banyak yang terbagi kedalam tiga bidang, yaitu aljabar, analisis dan geometri.

Matematika adalah disiplin ilmu yang mempelajari tentang tata cara berpikir dan mengolah logika, baik secara kuantitatif maupun secara kualitatif (Erman Suherman, 2003:298). Menurut Johnson dan Rising dalam bukunya yang dikutip oleh Erman Suherman (2003:17) mengatakan bahwa matematika adalah pola berpikir, pola mengkoordinasikan, pembuktian yang logik, matematika itu adalah bahasa yang menggunakan istilah yang didefinisikan dengan cermat, jelas, dan akurat, presentasinya dengan simbol dan padat, lebih berupa bahasa simbol mengenai ide daripada mengenai bunyi.

Pendidikan tidak terlepas dari kegiatan pembelajaran. Belajar menurut Spears dalam Suprijono (2009:2) adalah mengamati, membaca, meniru, mencoba sesuatu, mendengar dan mengikuti arah tertentu. Jadi belajar adalah proses perubahan perilaku secara aktif, proses mereaksi terhadap semua situasi yang ada di sekitar individu, proses yang diarahkan kepada suatu tujuan, proses berbuat melalui berbagai pengalaman, proses melihat, mengamati, memahami sesuatu yang dipelajari.

Realitas saat ini, masih banyak peserta didik yang memiliki masalah dalam belajarnya dengan nilai-nilai yang selalu rendah dan tidak memiliki semangat dalam belajar yang baik. Sungguh ironi yang perlu dituntaskan sampai ke akar-akarnya. Peran orang tua juga harus ikut mendukung, di rumah peserta didik harus diajarkan kembali di pantau jangan sampai peserta didik hanya banyak bermain saja. Supaya peserta didik-siswi mendapatkan nilai yang tinggi dan memuaskan terutama dalam mata pelajaran Matematika.

Dalam proses belajar mengajar guru dituntut untuk dapat mewujudkan dan menciptakan situasi yang memungkinkan peserta didik untuk aktif dan kreatif. Pada sistem ini diharapkan peserta didik dapat secara optimal melaksanakan aktivitas belajar sehingga tujuan instruksional yang telah ditetapkan dapat tercapai secara maksimal.

Kegiatan belajar adalah kegiatan yang rumit karena tidak sekedar menyerap informasi dari guru, tetapi melibatkan berbagai kegiatan maupun tindakan yang harus dilakukan terutama jika diinginkan hasil yang baik. Salah satu pembelajaran yang menekankan berbagai tindakan adalah 
menggunakan metode tertentu dalam pembelajaran. Pendekatan dalam pembelajaran merupakan suatu upaya dalam mengembangkan keaktifan belajar. Saat ini khususnya guru di SDN 156/X Tanjung Solok masih menggunakan metode pembelajaran konvensional dimana guru menerangkan dan murid hanya mendengarkan penjelasan guru serta mencatat, sehingga di SDN 156/X Tanjung Solok perlu diterapkan metode pembelajaran kooperatif atau berdiskusi.

Untuk mengatasi masalah yang berkelanjutan maka perlu diterapkan metode pembelajaran yang tepat sehingga dapat meningkatkan keaktifan peserta didik dalam pembelajaran matematika. Metode tersebut adalah metode pembelajaran diskusi. Metode diskusi merupakan metode yang membuat para peserta didik aktif karena semua peserta didik memperoleh kesempatan berbicara atau berdialog satu sama lain untuk bertukar pikiran dan informasi tentang suatu topik atau masalah, atau mencari kemungkinan fakta dan pembuktian yang dapat digunakan bagi pemecahan suatu masalah. Dengan menggunakan metode diskusi dalam proses belajar mengajar matematika diharapkan agar peserta didik lebih aktif dalam belajar, sehingga peserta didik lebih bergairah dan bersemangat dalam mempelajari matematika serta dapat mengaplikasikan dalam kehidupan sehari-hari.

Pada zaman modern diskusi telah dianggap sebagai salah satu cirri penting sebuah kelas yang demokratis, yang didefinisikan sebagai suatu kegiatan di mana orang-orang berbicara bersama untuk berbagi dan saling tukar informasi tentang sebuah topic atau masalah atau mencari pemecahan terhadap suatu masalah berdasarkan bukti-bukti yang ada. (Abdul Azis, 2007: 100). Selama ini telah terjadi kecenderungan dalam memberikan makna mutu pendidikan yang hanya dikaitkan dengan aspek kemampuan kognitif. Pandangan ini telah membawa akibat terabaikannya aspek-aspek moral, akhlak, budi pekerti, seni, psikomotor, serta life skill. Dengan diterbitkannya Undang-undang Nomor 20 Tahun 2003 tentang Sistem Pendidikan Nasional dan Peraturan Pemerintah Nomor 19 Tahun 2005 tentang Standar Nasional Pendidikan akan memberikan peluang untuk menyempurnakan kurikulum yang komprehensif dalam rangka mencapai tujuan pendidikan nasional.

Berdasarkan atas evaluasi peneliti selama mengajar di kelas IV SDN 156/X Tanjung Solok, terdapat beberapa kendala dalam pencapaian hasil belajar yang optimal. Dari beberapa kali diberikan penilaian ternyata hasil belajarnya masih tetap rendah walau telah diberikan berbagai metode atau metode pembelajaran. Sebenarnya yang menjadi bidang kajian peneliti ini adalah rendahnya hasil belajar peserta didik untuk mata pelajaran Matematika di kelas IV SDN 156/X Tanjung Solok. Untuk meningkatkan hasil belajar peserta didik tersebut secara maksimal, maka perlu perbaikan metode pembelajaran yaitu melalui Metode Pembelajaran Diskusi. Metode diskusi yaitu untuk melatih murid agar mengembangkan ide-ide dan melatih kepercayaan diri agar berani mengutarakan pendapatnya di hadapan umum. Memecahkan masalah secara bersama dengan menghargai pendapat orang lain.

Penelitian ini dilakukan untuk memecahkan masalah yang selama ini menyebabkan guru resah, gelisah dengan banyaknya nilai peserta didik tidak tuntas sesuai dengan nilai ketuntasan minimal (KKM). Padahal guru selama ini telah menerapkan yang namanya Pembelajaran kontekstual, 
Upaya Meningkatkan Hasil Belajar Matematika Materi Keliling dan Luas Lingkaran Pada Peserta Didik Melalui Metode Diskusi di Kelas IV SDN 156/X Tanjung Solok Semester Ganjil Tahun Ajaran 2021/2022, Nuraini

dimana pusat pembelajaran sudah berada pada peserta didik dan guru hanya sebagai pemotifator dan fasilitator.

Menurut Bower (1987:150) Belajar dapat menunjukan adanya perubahan yang relatif dalam perilaku yang terjadi karena adanya beberapa pengalaman yang telah dialami dan juga latihan yang sudah dilakukan dalam waktu sebelumnya. Bower juga menjelaskan bahwa "Learning is a cognitive process" yang artinya Belajar adalah suatu proses kognitif. Disini Bower menjelaskan proses merupakan hal yang lebih penting dibandingkan hasil dari belajar itu sendiri.

Menurut Sudjana, (2004: 22) hasil belajar adalah kemampuan-kemampuan yang dimiliki peserta didik setelah menerima pengalaman belajarnya. Menurut Hamalik (2004: 49) "Mendefinisikan hasil belajar sebagai tingkat penguasaan yang dicapai oleh pelajar dalam mengikuti proses belajar mengajar sesuai dengan tujuan pendidikan yang ditetapkan". Sedangkan Winkel (2009) mengemukakan bahwa "hasil belajar merupakan bukti keberhasilan yang telah dicapai oleh seseorang”.

Belajar merupakan proses yang dilakukan seseorang untuk mendapatkan perubahan tingkah laku sebagai hasil interaksi dengan lingkungannya (Sugihartono, 2007: 74). Senada dengan pendapat tersebut, belajar menurut Sardiman (2011:21) adalah berubah. Dalam hal ini yang dimaksudkan belajar berarti usaha mengubah tingkah laku. Jadi belajar akan membawa suatu perubahan pada individu-individu yang belajar.

Belajar (Wina Sanjaya, 2009: 107) adalah proses berpikir. Belajar berpikir yaitu menekankan pada proses mencari dan menemukan pengetahuan melalui interaksi antar individu dengan lingkungannya. Belajar menurut Klien dalam Conny (2008:4) adalah proses pengalaman yang menghasilkan perubahan perilaku yang relatif permanen dan yang tidak dapat dijelaskan dengan kedewasaan, atau tendensi alamiah. Artinya memang belajar tidak terjadi karena proses kematangan dari dalam saja melainkan juga karena pengalaman yang perolehannya bersifat eksistensial.

Metode diskusi merupakan kegiatan pembelajaran yang membincangkan suatu topic atau masalah yang dilakukan dua orang atau lebih, di mana orang-orang yang berbincang tersebut memiliki perhatian yang sama terhadap topic atau masalah yang didiskusikan. (Ellizar Jalius, Pengembangan Program Pembelajaran, Halaman 53).

Pada jaman modern diskusi telah dianggap sebagai salah satu cirri penting sebuah kelas yang demokratis, yang didefinisikan sebagai suatu kegiatan di mana orang-orang berbicara bersama untuk berbagi dan saling tukar informasi tentang sebuah topic atau masalah atau mencari pemecahan terhadap suatu masalah berdasarkan bukti-bukti yang ada.

\section{METODE}

Jenis penelitian ini adalah penelitian tindakan kelas. Penelitian ini dilaksanakan di SDN 156/X tanjung Solok pada semester ganjil, tahun ajaran 2021/2022. Subjek dalam penelitian ini adalah siswa IV dengan jumlah peserta didik 5 orang. Prosedur penelitian ini meliputi perencanaan, 
pelaksanaan, pengamatan, dan refleksi. Penelitian ini dilaksanakan dalam dua siklus, masing-masing siklus terdiri dari dua kali pertemuan. Teknik yang digunakan dalam pengumpulan data adalah observasi, tes, catatan lapangan dan dokumentasi. Data dianalisis melalui persentase dan reduksi data.

\section{HASIL DAN DISKUSI}

\section{Siklus I}

1. Perencanaan

Penerapan metode diskusi untuk meningkatkan aktivitas belajar peserta didik berpedoman dari langkah-langkah penelitian yang dirumuskan dalam prosedur penelitian. aktivitas yang dilakukan antara lain membuat jadwal penelitian tindakan kelas, menentukan materi yang akan dilaksanakan pada waktu penelitian agar mengetahui kompetensi dasar yang akan disampaiakan kepada peserta didik dalam pembelajaran. Kemudian mempersiapkan silabus. mempersiapkan rencana pelaksaan pembelajaran dengan mengacu pada tindakan yang diterapkan dalam PTK. Menyiapkan media yang akan dipakai pada saat penelitian. Membagi peserta didik dalam beberapa kelompok.

2. Pelaksanaan

Pertemuan pertama siklus I dilakukan pada hari Selasa, tanggal 7 September 2021 dengan materi keliling Lingkaran. Langkah selanjutnya adalah melaksanakan tindakan skenario pembelajaran sesuai dengan yang telah di rencanakan bersama kolaborator untuk setiap siklus tindakan yang dilakukan mengikuti tahapan sebagai berikut. Tahapannya terdiri dari kegiatan pendahuluan, inti, dan penutup. Pada kegiatan pendahuluan ini kelas dilakukan pembukaan dengan salam pembuka dan berdoa untuk memulai pembelajaran, memeriksa kehadiran peserta didik sebagai sikap disiplin. Kemudian Mengaitkan materi pembelajaran yang akan dilakukan dengan pengalaman peserta didik terhadap materi sebelumnya, mengingatkan kembali materi dengan bertanya. Memberikan gambaran tentang manfaat mempelajari materi Keliling Lingkaran dalam kehidupan sehari-hari. Memberitahukan tentang tujuan pembelajaran, materi, kompetensi inti, kompetensi dasar, indikator, dan KKM pada pertemuan yang sedang berlangsung. Setelah itu Pembagian kelompok belajar terdiri dari 2 kelompok.

Pada kegiatan inti ini peserta didik diberi stimulus atau rangsangan untuk memusatkan perhatian pada materi Keliling Lingkaran melalui pendekatan saintifik (mengamati, menanya, mengumpulkan informasi/eksperimen, mengasosiasikan mengolah informasi, mengomunikasikan). Kemudian peserta didik bersama kelompoknya melakukan pengamatan dari permasalahan yang ada di buku paket berkaitan dengan materi Keliling Lingkaran.

Guru memberikan kesempatan pada peserta didik untuk mengidentifikasi aneka pertanyaan yang berkaitan dengan tayangan yang disajikan dan dijawab melalui kegiatan pembelajaran tentang Keliling Lingkaran Misalnya Sebuah lingkaran memiliki jari-jari $14 \mathrm{~cm}$. Berapakah keliling lingkaran tersebut?. Peserta didik dibentuk dalam beberapa kelompok untuk mendiskusikan, mengumpulkan informasi, mempresentasikan ulang, dan saling bertukar informasi mengenai Keliling Lingkaran. 
Upaya Meningkatkan Hasil Belajar Matematika Materi Keliling dan Luas Lingkaran Pada Peserta Didik Melalui Metode Diskusi di Kelas IV SDN 156/X Tanjung Solok Semester Ganjil Tahun Ajaran 2021/2022, Nuraini

Mengumpulkan data/informasi melalui diskusi kelompok atau kegiatan lain guna menemukan solusimasalah terkait materi pokok. Peserta didik diarahkan untuk mengumpulkan dan mengeksplorasi data dari aneka sumber yang akan digunakan untuk menyelesaikan permasalahan di Lembar Kerja Peserta Didik (LKPD).

Setelah itu guru menugaskan peserta didik untuk mempresentasikan hasil diskusi kelompok secara klasikal, mengemukakan pendapat atas presentasi yang dilakukan tentang Keliling Lingkaran dan ditanggapi oleh kelompok yang mempresentasikan, bertanya atas presentasi yang dilakukan, dan peserta didik lain diberi kesempatan untuk menjawabnya. Guru dan Peserta didik menarik sebuah kesimpulan tentang point-point penting yang muncul dalam kegiatan pembelajaran yang baru dilakukan tentang Keliling Lingkaran. Peserta didik bertanya tentang hal yang belum dipahami atau guru menyampaikan beberapa pertanyaan pemicu kepada peserta didik berkaitan dengan yang akan selesai dipelajari.

Pada kegiatan penutup ini peserta didik Membuat rangkuman/simpulan pelajaran tentang point-point penting yang muncul dalam kegiatan pembelajaran yang baru dilakukan. Memeriksa pekerjaan peserta didik yang selesai dan diberi paraf serta diberi nomor urut peringkat, memberikan penghargaan pada kelompok yang memiliki kinerja dan kerja sama yang baik dalam kegiatan pembelajaran. Setelah itu memberikan tugas kepada peserta didik (PR), dan mengingatkan peserta didik untuk mempelajari materi yang akan dibahas dipertemuan berikutnya.

Pertemuan kedua dilaksanakan pada hari Selasa, 14 September 2021 dengan materi keliling lingkaran Langkah selanjutnya adalah melaksanakan tindakan skenario pembelajaran sesuai dengan yang telah di rencanakan bersama kolaborator untuk setiap siklus tindakan yang dilakukan mengikuti tahapan sebagai berikut. Pada kegiatan pendahuluan ini kelas dilakukan pembukaan dengan salam pembuka dan berdoa untuk memulai pembelajaran, memeriksa kehadiran peserta didik sebagai sikap disiplin. Kemudian Mengaitkan materi pembelajaran yang akan dilakukan dengan pengalaman peserta didik terhadap materi sebelumnya, mengingatkan kembali materi dengan bertanya. Memberikan gambaran tentang manfaat mempelajari materi Keliling Lingkaran dalam kehidupan sehari-hari. Memberitahukan tentang tujuan pembelajaran, materi, kompetensi inti, kompetensi dasar, indikator, dan KKM pada pertemuan yang sedang berlangsung. Setelah itu Pembagian kelompok belajar terdiri dari 2 kelompok.

Pada kegiatan inti ini peserta didik diberi stimulus atau rangsangan untuk memusatkan perhatian pada materi Keliling Lingkaran melalui pendekatan saintifik (mengamati, menanya, mengumpulkan informasi/eksperimen, mengasosiasikan mengolah informasi, mengomunikasikan). Kemudian peserta didik bersama kelompoknya melakukan pengamatan dari permasalahan yang ada di buku paket berkaitan dengan materi Keliling Lingkaran.

Guru memberikan kesempatan pada peserta didik untuk mengidentifikasi aneka pertanyaan yang berkaitan dengan tayangan yang disajikan dan dijawab melalui kegiatan pembelajaran tentang Keliling Lingkaran Misalnya "Sebuah lingkaran memiliki jari-jari $14 \mathrm{~cm}$. Berapakah keliling 
lingkaran tersebut?". Peserta didik dibentuk dalam beberapa kelompok untuk mendiskusikan, mengumpulkan informasi, mempresentasikan ulang, dan saling bertukar informasi mengenai Keliling Lingkaran. Mengumpulkan data/informasi melalui diskusi kelompok atau kegiatan lain guna menemukan solusimasalah terkait materi pokok. Peserta didik diarahkan untuk mengumpulkan dan mengeksplorasi data dari aneka sumber yang akan digunakan untuk menyelesaikan permasalahan di Lembar Kerja Peserta Didik (LKPD).

Setelah itu peserta didik ditugaskan untuk mempresentasikan hasil diskusi kelompok secara klasikal, mengemukakan pendapat atas presentasi yang dilakukan tentang Keliling Lingkaran dan ditanggapi oleh kelompok yang mempresentasikan, bertanya atas presentasi yang dilakukan, dan peserta didik lain diberi kesempatan untuk menjawabnya. Guru dan Peserta didik menarik sebuah kesimpulan tentang point-point penting yang muncul dalam kegiatan pembelajaran yang baru dilakukan tentang Keliling Lingkaran. Peserta didik bertanya tentang hal yang belum dipahami atau guru menyampaikan beberapa pertanyaan pemicu kepada peserta didik berkaitan dengan yang akan selesai dipelajari.

Pada kegiatan penutup ini peserta didik Membuat rangkuman/simpulan pelajaran tentang point-point penting yang muncul dalam kegiatan pembelajaran yang baru dilakukan. Memeriksa pekerjaan peserta didik yang selesai dan diberi paraf serta diberi nomor urut peringkat, memberikan penghargaan pada kelompok yang memiliki kinerja dan kerja sama yang baik dalam kegiatan pembelajaran. Setelah itu memberikan tugas kepada peserta didik (PR), dan mengingatkan peserta didik untuk mempelajari materi yang akan dibahas dipertemuan berikutnya.

\section{Observasi}

Sesuai dengan tujuan peneliti yang telah dikemukakan sebelumnya yaitu untuk meningkatkan aktivitas belajar peserta didik pada pembelajaran Matematika melalui penerapan metode diskusi dikelas IV SDN 156/X Tanjung Solok dengan indikator belajar peserta didik yaitu: Mengerjakan tugas kelompok, Bertanya dalam kelompok, Menjawab Pertanyaan, Menanggapi tugas kelompok. Distribusi persentase frekuensi hasil belajar dapat dilihat dari hasil analisis data pada tabel berikut.

Tabel 1. Hasil Tes Formatif Siklus I

\begin{tabular}{|c|l|l|}
\hline No & \multicolumn{1}{|c|}{ Uraian } & \multicolumn{1}{|c|}{ Hasil } \\
\hline 1 & Jumlah Nilai & 270 \\
\hline 2 & Rata-rata Nilai & 54.00 \\
\hline 3 & Peserta didik Tuntas & 2 \\
\hline 4 & Peserta didik Tidak Tuntas & 3 \\
\hline 5 & Persentase Peserta didik Tuntas & $40 \%$ \\
\hline 6 & Persentase Peserta didik Tidak Tuntas & $60 \%$ \\
\hline
\end{tabular}

Berdasarkan tabel 1 dapat dilihat bahwa rata-rata nilai yang didapat dari hasil tes formatif siklus I sebesar 54,00, dan dari hasil observasi hasil belajar peserta didik pada siklus I yang tuntas sebanyak 2 
Upaya Meningkatkan Hasil Belajar Matematika Materi Keliling dan Luas Lingkaran Pada Peserta Didik Melalui Metode Diskusi di Kelas IV SDN 156/X Tanjung Solok Semester Ganjil Tahun Ajaran 2021/2022, Nuraini

orang atau sebesar $40 \%$. Oleh karena itu dapat dilihat bahwa hasil belajar peserta didik pada setiap pertemuan mengalami peningkatan namun belum mencapai target yang ditentukan yaitu sebesar $80 \%$.

\section{Refleksi}

Berdasarkan hasil analisis data observasi bersama guru mitra sebagai obsever yaitu Asniwati, S.Pd.SD. yang dilakukan pada hari Jumat, tanggal 17 September 2021 yang dilakukan di kantor majelis guru, dapat disimpulkan refleksi pada siklus I, dengan dua kali pertemuan bahwa penggunaan metode diskusi dalam bentuk kerja kelompok dan tanya jawab cukup mempengaruhi hasil belajar peserta didik.

Setelah dilihat dari semua indikator yang dikemukakan dari penelitian secara total belum mencapai target yang di inginkan artinya jumlah peserta didik yang tuntas masih di bawah $80 \%$, namun ada beberapa kelemahan yang di temukan pada siklus I. Pertama sekali sifat malas pada diri peserta didik, kurangnya buku sumber yang dipakai peserta didik dan hanya mengandalkan rangkuman materi yang diberikan oleh guru. Masih banyak peserta didik yang belum aktif dimana yang bertanya dan mengerjakan tugas hanya orang-orang tetap yang itu saja terutama pada indikatorindikator aktivitas tertentu hal ini diakibatkan oleh adanya rasa malu terhadap teman sekelas dan tidak percaya diri atau takut salah dalam mengemukakan pendapat di depan teman-temannya, ini karna semua kebiasaan peserta didik yang masih mendapat materi hanya tertumpu pada metode ceramah dari guru.

Berdasarkan kelemahan-kelemahan yang ditemukan dalam siklus I maka perlu dicarikan solusi dengan melakukan revisi terhadap tindakan yang dilakukan antara lain: 1) pertama sekali guru harus merubah pandangan peserta didik terhadap penyampaian materi yang tertumpu pada ceramah dari guru saja 2) Guru membimbing peserta didik untuk merumuskan pertanyaan, menjawab dan berpendapat, sehingga relevan dengan materi yang didiskusikan. Oleh karena itu guru diharapakan mampu untuk mengatasi kekurangan waktu harus bisa mengatur jalannya diskusi agar tidak larut dalam satu pertanyaan atau tanggapan yang relevan, mempersiapkan hadih bagi peserta didik yang paling aktif bertanya dalam berdiskusi. Oleh karena itu penelitian ini dilanjutkan ke siklus berikutnya.

\section{SIKLUS II}

\section{Perencanaan}

Pelaksanaan metode diskusi untuk meningkatkan hasil belajar peserta didik berpedoman dari langkah-langkah penelitian yang dirumuskan dalam prosedur penelitian. aktivitas yang dilakukan antara lain membuat jadwal lanjutan penelitian tindakan kelas, menentukan materi lanjutan dari siklus I yang akan dilaksanakan pada waktu penelitian pada siklus II agar mengetahui kompetensi dasar yang akan disampaiakan kepada peserta didik dalam pembelajaran. Selain itu mempersiapkan silabus. Mempersiapkan rencana pelaksanaan pembelajaran lanjutan dengan mengacu pada tindakan yang diterapkan dalam PTK. Menyiapkan media yang akan dipakai pada saat penelitian. Membagi peserta didik dalam beberapa kelompok, dan Menyiapkan reward/hadiah. 


\section{Pelaksanaan}

Pertemuan pertama dilakukan pada hari Selasa, 5 Oktober 2021 dengan materi Luas Lingkaran. indikator pencapaian pada pertemuan pertama ini adalah peserta didik dapat menjelaskan taksiran luas lingkaran. Kemudian menaksir luas lingkaran serta menggunakannya untuk menyelesaikan masalah.

Pada kegiatan pendahuluan ini kelas dilakukan pembukaan dengan salam pembuka dan berdoa untuk memulai pembelajaran, memeriksa kehadiran peserta didik sebagai sikap disiplin. Kemudian Mengaitkan materi pembelajaran yang akan dilakukan dengan pengalaman peserta didik terhadap materi sebelumnya, mengingatkan kembali materi dengan bertanya. Memberikan gambaran tentang manfaat mempelajari materi Keliling Lingkaran dalam kehidupan sehari-hari. Memberitahukan tentang tujuan pembelajaran, materi, kompetensi inti, kompetensi dasar, indikator, dan KKM pada pertemuan yang sedang berlangsung. Setelah itu Pembagian kelompok belajar terdiri dari 2 kelompok.

Pada kegiatan inti ini peserta didik diberi stimulus atau rangsangan untuk memusatkan perhatian pada materi Luas Lingkaran melalui pendekatan saintifik (mengamati, menanya, mengumpulkan informasi/eksperimen, mengasosiasikan mengolah informasi, mengomunikasikan). Kemudian peserta didik bersama kelompoknya melakukan pengamatan dari permasalahan yang ada di buku paket berkaitan dengan materi Luas Lingkaran. Guru memberikan kesempatan pada peserta didik untuk mengidentifikasi aneka pertanyaan yang berkaitan dengan tayangan yang disajikan dan dijawab melalui kegiatan pembelajaran tentang Luas Lingkaran Misalnya Sebuah lingkaran memiliki panjang diameter $35 \mathrm{~cm}$. Tentukanlah keliling lingkaran dan luas lingkaran?.

Peserta didik dibentuk dalam beberapa kelompok untuk mendiskusikan, mengumpulkan informasi, mempresentasikan ulang, dan saling bertukar informasi mengenaiLuas Lingkaran. Mengumpulkan data/informasi melalui diskusi kelompok atau kegiatan lain guna menemukan solusimasalah terkait materi pokok. Peserta didik diarahkan untuk mengumpulkan dan mengeksplorasi data dari aneka sumber yang akan digunakan untuk menyelesaikan permasalahan di Lembar Kerja Peserta Didik (LKPD).

Mempresentasikan hasil diskusi kelompok secara klasikal, mengemukakan pendapat atas presentasi yang dilakukan tentang Luas Lingkaran dan ditanggapi oleh kelompok yang mempresentasikan, bertanya atas presentasi yang dilakukan, dan peserta didik lain diberi kesempatan untuk menjawabnya. Guru dan Peserta didik menarik sebuah kesimpulan tentang point-point penting yang muncul dalam kegiatan pembelajaran yang baru dilakukan tentang Luas Lingkaran. Peserta didik bertanya tentang hal yang belum dipahami atau guru menyampaikan beberapa pertanyaan pemicu kepada peserta didik berkaitan dengan yang akan selesai dipelajari.

Pada kegiatan penutup ini peserta didik Membuat rangkuman/simpulan pelajaran tentang point-point penting yang muncul dalam kegiatan pembelajaran yang baru dilakukan. Memeriksa pekerjaan peserta didik yang selesai dan diberi paraf serta diberi nomor urut peringkat, memberikan 
Upaya Meningkatkan Hasil Belajar Matematika Materi Keliling dan Luas Lingkaran Pada Peserta Didik Melalui Metode Diskusi di Kelas IV SDN 156/X Tanjung Solok Semester Ganjil Tahun Ajaran 2021/2022, Nuraini

penghargaan pada kelompok yang memiliki kinerja dan kerja sama yang baik dalam kegiatan pembelajaran. Setelah itu Memberikan tugas kepada peserta didik (PR), dan mengingatkan peserta didik untuk mempelajari materi yang akan dibahas dipertemuan berikutnya.

Pertemuan kedua dilakukan pada hari Selasa, 12 Oktober 2021 dengan materi Luas Lingkaran. indikator pencapaian pada pertemuan pertama ini adalah peserta didik dapat menjelaskan taksiran luas lingkaran. Kemudian menaksir luas lingkaran serta menggunakannya untuk menyelesaikan masalah. Pada kegiatan pendahuluan ini kelas dilakukan pembukaan dengan salam pembuka dan berdoa untuk memulai pembelajaran, memeriksa kehadiran peserta didik sebagai sikap disiplin. Kemudian Mengaitkan materi pembelajaran yang akan dilakukan dengan pengalaman peserta didik terhadap materi sebelumnya, mengingatkan kembali materi dengan bertanya. Memberikan gambaran tentang manfaat mempelajari materi Keliling Lingkaran dalam kehidupan sehari-hari. Memberitahukan tentang tujuan pembelajaran, materi, kompetensi inti, kompetensi dasar, indikator, dan KKM pada pertemuan yang sedang berlangsung. Setelah itu Pembagian kelompok belajar terdiri dari 2 kelompok.

Pada kegiatan inti ini peserta didik diberi stimulus atau rangsangan untuk memusatkan perhatian pada materi Luas Lingkaran melalui pendekatan saintifik (mengamati, menanya, mengumpulkan informasi/eksperimen, mengasosiasikan mengolah informasi, mengomunikasikan). Kemudian peserta didik bersama kelompoknya melakukan pengamatan dari permasalahan yang ada di buku paket berkaitan dengan materi Luas Lingkaran

Guru memberikan kesempatan pada peserta didik untuk mengidentifikasi aneka pertanyaan yang berkaitan dengan tayangan yang disajikan dan dijawab melalui kegiatan pembelajaran tentang Luas Lingkaran Misalnya Sebuah lingkaran memiliki panjang diameter $35 \mathrm{~cm}$. Tentukanlah keliling lingkaran dan luas lingkaran?.

Peserta didik dibentuk dalam beberapa kelompok untuk mendiskusikan, mengumpulkan informasi, mempresentasikan ulang, dan saling bertukar informasi mengenaiLuas Lingkaran. Mengumpulkan data/informasi melalui diskusi kelompok atau kegiatan lain guna menemukan solusimasalah terkait materi pokok. Peserta didik diarahkan untuk mengumpulkan dan mengeksplorasi data dari aneka sumber yang akan digunakan untuk menyelesaikan permasalahan di Lembar Kerja Peserta Didik (LKPD).

Mempresentasikan hasil diskusi kelompok secara klasikal, mengemukakan pendapat atas presentasi yang dilakukan tentang Luas Lingkaran dan ditanggapi oleh kelompok yang mempresentasikan, bertanya atas presentasi yang dilakukan, dan peserta didik lain diberi kesempatan untuk menjawabnya. Guru dan Peserta didik menarik sebuah kesimpulan tentang point-point penting yang muncul dalam kegiatan pembelajaran yang baru dilakukan tentang Luas Lingkaran. Peserta didik bertanya tentang hal yang belum dipahami atau guru menyampaikan beberapa pertanyaan pemicu kepada peserta didik berkaitan dengan yang akan selesai dipelajari. 
Pada kegiatan penutup ini peserta didik Membuat rangkuman/simpulan pelajaran tentang point-point penting yang muncul dalam kegiatan pembelajaran yang baru dilakukan. Memeriksa pekerjaan peserta didik yang selesai dan diberi paraf serta diberi nomor urut peringkat, memberikan penghargaan pada kelompok yang memiliki kinerja dan kerja sama yang baik dalam kegiatan pembelajaran. Setelah itu Memberikan tugas kepada peserta didik (PR), dan mengingatkan peserta didik untuk mempelajari materi yang akan dibahas dipertemuan berikutnya.

\section{Observasi}

Sesuai dengan tujuan peneliti yang telah dikemukakan sebelumnya yaitu untuk meningkatkan hasilbelajar peserta didik pada muatan matematika melalui penerapan metode diskusi di kelas IV SDN 156/X Tanjung Solok. Distribusi persentase frekuensi hasil belajar dapat dilihat dari hasil analisis data pada tabel berikut.

Tabel 2. Hasil Tes Formatif Siklus I

\begin{tabular}{|c|l|l|}
\hline No & \multicolumn{1}{|c|}{ Uraian } & \multicolumn{1}{c|}{ Hasil } \\
\hline 1 & Jumlah Nilai & 360 \\
\hline 2 & Rata-rata Nilai & 72.00 \\
\hline 3 & Peserta didik Tuntas & 4 \\
\hline 4 & Peserta didik Tidak Tuntas & 1 \\
\hline 5 & Persentase Peserta didik Tuntas & 80 \\
\hline 6 & Persentase Peserta didik Tidak Tuntas & 20 \\
\hline
\end{tabular}

Berdasarkan tabel 2 diatas dapat dilihat bahwa dari rata-rata nilai yaitu 72,00 dan jumlah peserta didik yang tuntas sebesar 4 orang atau dengan persentase $80 \%$. Dari hasil observasi hasil belajar peserta didik pada siklus II dapat dilihat bahwa hasil belajar peserta didik pada setiap pertemuan mengalami peningkatan dan telah mencapai target ditentukan yaitu $80 \%$.

\section{Refleksi}

Berdasarkan hasil analisis data observasi bersama guru mitra sebagai obsever Asniwati, S.Pd.SD. yang dilakukan pada hari Jumat, tanggal 15 Oktober 2021 yang dilakukan di kantor majelis guru dapat disimpulkan refleksi pada siklus II, dengan dua kali pertemuan bahwa penggunaan metode diskusi sangat mempengaruhi hasil belajar peserta didik. Hal ini dapat dilihat dari rekapitulasi pada siklus II hasil belajar meningkat menjadi $80 \%$, sudah melebihi dari target yang dikehendaki yaitu sebesar 80\%. Berdasarkan kelemahan-kelemahan yang ditemukan pada siklus II, maka perlu dicarikan solusi dengan melakukan revisi terhadap tindakan yang dilakukan antara lain: 1) Guru sudah berperan aktif memberi motivasi pada sebagian peserta didik yang masih memilki sifat malas, agar sifat tersebut bisa dihilangkan pada semua peserta didik, dengan memberikan penghargaan dan mengumumkan jumlah poin yang di kumpulkan tiap kelompok. 2) Guru sudah membimbing peserta didik untuk merumuskan pertanyaan, menjawab dan berpendapat, sehingga relevan dengan materi yang didiskusikan, 3) Guru sudah mampu untuk mengatasi kekurangan waktu harus bisa mengatur jalannya diskusi agar tidak larut dalam satu pertanyaan atau tanggapan yang relevan, 4) dikarenakan 
Upaya Meningkatkan Hasil Belajar Matematika Materi Keliling dan Luas Lingkaran Pada Peserta Didik Melalui Metode Diskusi di Kelas IV SDN 156/X Tanjung Solok Semester Ganjil Tahun Ajaran 2021/2022, Nuraini

ada tindakan pemberian reward/hadiah bagi peserta didik yang paling aktif dalam bertanya. Oleh karena itu penelitian ini tidak dilanjutkan ke siklus berikutnya.

\section{Diskusi}

Dari temuan yang didapat pada siklus pertama dan siklus kedua berkaitan dengan aktivitas belajar peserta didik mengenai pembelajaran Matematika setelah menggunakan metode diskusi yang terdiri dari dua kali pertemuan berinti pada aspek-aspek yang di amati ternyata bahwa hasil belajar meningkat. Sementara itu rendahnya aktivitas peserta didik pada bertanya dalam kelompok berdasarkan peserta didik disebabkan oleh hal-hal di bawah ini: 1) beberapa peserta didik yang masih memiliki sifat malas mengikuti pelajaran atau rendahnya mental peserta didik untuk belajar 2) rendahnya kemampuan sisiwa memahami materi yang diberikan, 3) masih kurangnya kemampuan peserta didik mengemukakan ide dan pendapat, karena terpaku pada bahan ajar dari guru.

Pada temuan tersebut sesuai dengan pendapat Sudjana (2005) dimana pendapat tersebut berkesimpulan bahwa aktivitas belajar peserta didik mencakup dua hal yang tak terpisahkan, yakni aktivitas mental ( emosional, intelektual, dan sosial), serta aktivitas motorik (gerak fisik) kedua aspek tersebut berkaitan antara yang satu dengan yang lainnya saling mengisi dan saling menetukan, oleh sebab itu keliru bila kita berpendapat bahwa optimalnya cara belajar peserta didik dilihat dari gerak motorik atau kegiatan mental semata-mata. Sementara itu peningkatan hasil belajar dapat dilihat pda grafik di bawah ini.

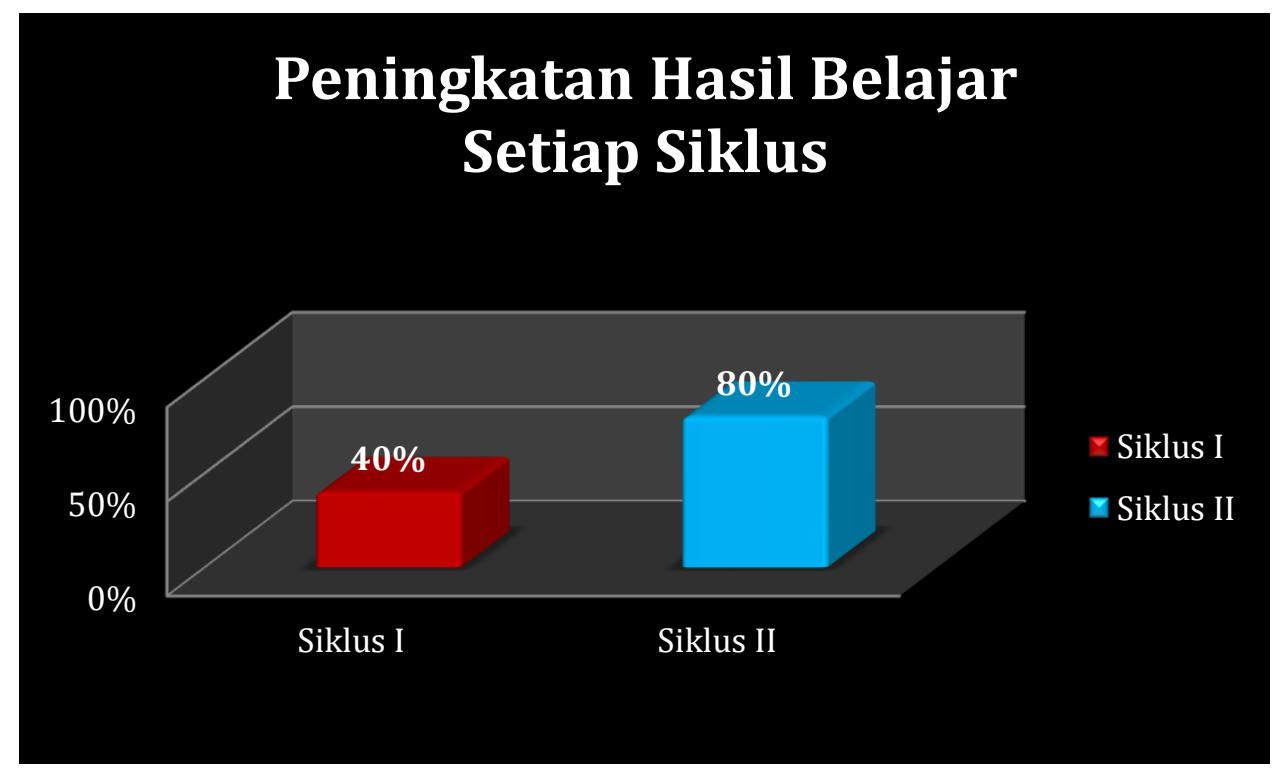

Gambar 1. Grafik Pencapaian KKM Klasikal

\section{KESIMPULAN}

Dari hasil dan pembahasan di atas dapat ditarik kesimpulan bahwasanya Upaya Meningkatkan Hasil Belajar Matematika Materi Keliling dan Luas Lingkaran Pada Peserta Didik Melalui Metode Diskusi di Kelas IV SDN 156/X Tanjung Solok Semester Ganjil tahun Ajaran 2021/2022, dapat dibuktikan berdasarkan tindakan yang dilakukan. Hasil pengamatan menunjukan 
bahwa hasil belajar peserta didik pada siklus I mencapai ketuntasan $40 \%$, meningkat pada siklus II menjad 80\% dengan tindakan pemberian reward/hadiah. Dengan menggunakan metode diskusi dapat meningkatkan hasil belajar peserta didik dalam pembelajaran Matematika, peserta didik lebih bersemangat untuk belajar dan mendapatkan hasil yang lebih baik disetiap siklus.

Berdasarkan simpulan dan implikasi dari pembelajaran Matematika dengan menggunakan metode diskusi, maka dapat dikemukakan beberapa saran antara lain kepada guru kelas IV SDN 156/X Tanjung Solok disarankan agar dapat memahami dan merancang pembelajaran dengan menggunakan model-model pembelajaran yang inovatif. Kepada guru kelas IV SDN 156/X Tanjung Solok disarankan agar dapat melaksanakan proses pembelajaran Matematika dengan menggunakan metode diskusi, karena metode ini dapat meningkatkan hasil belajar peserta didik. Kepada lembaga terkait melalui pembinaan SD, disarankan hasil penelitian ini dapat dijadikan alternatif untuk memperbaiki proses pembelajaran dan pedoman untuk melanjutkan penelitian selanjutnya, agar mencapai hasil yang lebih maksimal.

\section{REFERENSI}

Asma, Nur.2008. Metode Pembelajaran Kooperatif. padang: UNP Press

Azis Abdul Wahab (2007). Metode dan Metode-metode Mengajar. Bandung: Alfabeta

Engkoswara (1984). Dasar-dasar Metodologi Pengajaran. Bandung: Bina Aksara Jakarta.

Hamalik. 2008. Proses Belajar Mengajar. Bandung Bumi Aksara.

Jalius Ellizar (2010). Pengembangan Program pembelajaran. Padang: Universitas Negeri Padang Press.

Jalius, Ellizar. 2009. Pengembangan Program Pembelajaran. Padang: UNPPress.

Maryani, Enok \& Kartawidjaja, Omi. 1996. Pengantar Geografi Regional. Jurusan Pendidikan Geografi FIPS. IKIP. Bandung.

Ngalimun, 2012. Strategi dan Metode Pembelajaran. yogyakarta: Aswaja Pressindo

Purwanto, Ngalim. 2007. Psikologi Belajar. Jakarta: Raja Grafindo Persada.

Sardiman, A. dkk. 2003. Media Pendidikan, Pengertian, Pengembangan dan Pemanfatannya. Jakarta: PT Raja Grafindo Persada.

Sudjana, Nana. 2005. Penilaian Hasil Proses Belajar Mengajar, Bandung: PT Remaja Rosdikarya. 